place, that a visitor, " after spending several hours amongst the patients, and after a most searching inquiry, was bound to say he quitted the asylum an entire convert, and could not speak too highly of the judicious regulations, and care and attention paid to the patients in every department."

Every friend of humanity must rejoice at the progress which the humane system is making, not only in Hanwell, but in other public and private receptacles for the insane. The looker-on sees more of the game than the players; and the public attention is now so deeply riveted, that $I$ shall be greatly chagrined, if, within a few months from the present time, a Royal Commission is not issued, to make a searching inquiry into the state and practice of every madhouse in the kingdom; and if, within two years from this time, the old modes of treatment should possess one avowed advocate of reputation. If report speaks truly, the spirit of reform has reached even Bethlem Hospital; but of that hereafter. I am, Sir, yours obediently,

April 27, 1841.

A LOOKER-ON.

\section{PUERPERAL CONVULSIONS.}

\section{To the Editor of THE LANCET.}

SrR:-In your Journal appears a communication from Mr. Scott, of Mansfield, in which he solicits the opinion of his profes. sional brethren upon the treatment of puerperal convulsions. From the candid statement of Mr. S., I am led to believe that, in the instance to which he refers, neither skill or humanity were wanting on his part; but I would take this opportunity of strongly recommending your correspondent, should a similar case again occur in his practice, to make trial of opiate injections. This mode of treatment, of which $I$ have given detailed accounts in The Lancer, (vide vol. ii., 1838-39; vol. i., 1840-41, p. 229,) I have seen attended with the happiest results; and that, too, when all other remedial means had utterly failed. I am, with great respect, your obliged servant,

A. B. MADDock, M.D.

80, Judd-street, Brunswick-square, March 29, 1841.

\section{ST. BARTHOLOMEW'S HOSPITAL.}

\section{To the Editor of The LANCET.}

Sir :-Allow me, on behalf of the stu. dents of St. Bartholomew's, to deny the justice of the charges of neglect on the part of the lecturers, published in your last number. The medical officers and lecturers of this hospital, by their uniformly, gentle- manly, and liberal conduct, have gained too firm a hold on the gratitude and respect of the students, and stand too high in their estimation, to be in any way affected by unjust charges. I am, Sir, your obedient servant,

St. Bartholomew's Hospital, March 22, 1841 .

** What proof or confirmation of the truth of his charges has the correspondent in question to offer? His communication must be confidentially authenticated.

\section{ROYAL COLLEGE OF SURGEONS,}

The council of the college, desirous of furnishing to the public a correct list of their members, request that each member will be pleased to transmit to the secretary, between the 1 st of June and 1 st of July in every year by letter, a statement containing his name at full length, address and date of diploma, in his own handwriting, in order that it may be compared with the chronological list.

The council will be further obliged by the member stating in a similar manner when he has a degree in medicine, or the licence of the Society of A pothecaries.

The council will be glad to receive corresponding statements from the members of the Edinburgh or Dablin College of Surgeons, practising in England or Wales.

$$
\text { April 8, } 1841 \text {. }
$$

Edmund Belfour, Secretary.

\section{BOOKS RECEIVED.}

Analysis of the Pitville Saline Waters. By James Buckman, Chemist. 1841. Pp.15.

\section{TO CORRESPONDENTS.}

Communications have been received from Mr. G. A. Rees ; Mr. Houlton; Dr. Man. tell; Mr. Florance; Mr. Holt ; Dr. Serny. Mr. Lay's interesting paper on Chinese surgery shall appear in an early Number of our Juurnal.

The proposition of Senex is precisely what the most reflecting medical reformer's advocate, as he may ascertain upon re-examining their discussions. It would be discouraging, perhaps, to the existing bodies to say, that with their present reputation no one would thank them, under the new law, for any " honour" they could confer.

Mr. Rowe's letter arrived too late for in. sertion this week; it shall appear in our next.

Sir Charles Scudamore's article is in type, but we have been prevented publishing it this week from press of matter. 